\title{
What's Past Is Prologue: A Research Response to a Pandemic Tempest
}

\author{
Peter K. Dorhout \\ Vice President for Research \\ Iowa State University \\ dorhout@iastate.edu \\ https://orcid.org/0000-0002-7862-3270
}

$\mathrm{J}$

anuary 2020 began like most winter months had before-cold and windy in Manhattan, Kansas. Our team of partner universities known collectively as CERES (the Coalition for Epi Response, Engagement, and Science) ${ }^{1}$ was planning its spring advocacy meeting for late February 2020 in Washington, DC, and had secured Sen. Pat Roberts (R-KS) and USDA Undersecretary for Marketing and Regulatory Programs Greg Ibach for an afternoon meeting session on "Agricultural Biosecurity-Linking Science, Innovation, and Action." Particular attention was being paid to an emerging zoonotic disease threat in Asia, which was a new variant of Sudden Acute Respiratory Syndrome, or SARS, known as SARS-CoV-2. Its predecessor, the 2002 respiratory virus, SARS-CoV-1, is a coronavirus family virus that had emerged in China and had originated in palm civets with a disease reservoir likely in bats. ${ }^{2}$

It is the mission of CERES to protect and defend the agricultural industry against global threats, to respond to and recover from outbreaks, and to provide innovations for food security. Advocacy had begun by CERES in 2018 for USDA and the Department of Homeland Security to consider a land-grant university effort to address agricultural biosecurity: “Lincoln's Biodefense Strategy: Protecting the Agricultural Base." ${ }^{3}$ The advocacy meeting on February 25, 2020, began with a typical fanfare of introductions to the topic of agriculture biosecurity, particularly zoonotic diseases affecting livestock. Nevertheless, by this date, over 130 cases of the disease caused by SARSCoV-2, called COVID-19, had been confirmed in the U.S., and within a year, that number would exceed 28 million cases. ${ }^{4}$ No other infectious disease had accelerated to such infection numbers since the H1N1 influenza outbreak a little more than a century before. ${ }^{5}$

I was offered the opportunity to provide the introductory remarks to just over 75 scientists, federal officials, and their staff in attendance for the advocacy meeting. In my introductory remarks, ${ }^{6} \mathrm{I}$ noted that we were standing on the shore, watching the tempest approach:

"We have gathered here today to share and learn about the current and future challenges associated with keeping American - and global - food supplies safe, reliable, and plentiful. Although the economies of the world are intricately tied through global trade and supply, global peace and stability are connected to the most fundamental of all human needs: to be fed and to be healthy. Governmental policies are enacted to strengthen the binds that tie our investments and strategies to peace and stability, and it is through government and private sector investments in fundamental new discoveries and inventions that we, the scientists in the room, will provide new methodologies, reliable technologies, and advanced countermeasures to achieve those ends. 
"Before CERES was a Coalition for Epi Response, Engagement, and Science, she was the Roman Goddess of Grain. If you studied Roman or Greek mythology, you know that the Gods were servant Gods, charged to ensure humans would survive and thrive, with appropriate due reverence and fealty, of course. To accomplish this, Ceres realized that she needed to cooperate with the other Gods and Goddesses - sun, rain, seasons, and so forth - to deliver her charge to provide ample grains for a growing and thriving population.

"Our CERES today recognizes the same: to deliver on agricultural bio-security, we must collaborate and connect our talents in science and innovation that lead to action. Today, we are here to share our progress on our mission and to express the continued need to muster our forces, maybe even collaborate with the Greek God Ares to not only prepare for but to wage war on plant, animal, and zoonotic infectious diseases that threaten our very existence.

"I am an Eagle Scout. While in Scouting, I learned the importance of servant leadership. One summer, at the age of 14, I helped to lead a group of other young men on a twoweek trek through the mountainous wilderness of New Mexico - the other Scouts in the room will recognize the high adventure base, Philmont. I had learned the critical skills necessary to survive - camping, hiking, and orienteering - that gave me the credibility to lead. I was a skilled map reader, and I've been intrigued with maps ever since. They show us the way. The maps of the ancient world still fascinate me.

"Roman, Greek, and Chinese ex- plorers, among others, charted the great unknowns. Those unexplored parts on the ancient maps were often denoted with ominous markings jagged mountains, dark jungles, violent stormy seas, and statements like 'here there be dragons.' Warnings about the terrible unknowns; harbingers of things to come; places where plagues were known to exist; places from which ill-prepared explorers never returned. Places where the tempest may deposit us. Places where the Gods feared to tread. Here there be dragons!

"We are at a critical crossroads today as we chart our course through time. With more than three times the population today on earth than were alive when I was born six decades ago, peace and prosperity across the human species are menaced by food, animal and human diseases and losses. Rapidly evolving viruses and other zoonotic pathogens threaten our production plants and animals and our own species - here there be dragons. Uncoordinated responses that are reactive and not proactive confirm the philosophers' rule that history shows again and again how nature points out the folly of man. I hope we are not witnessing the prologue."

Within 3 weeks of the CERES advocacy meeting, the number of cases in the U.S. had increased over 200 times, and universities were bracing for the storm, preparing to shut down all operations, including research, in an effort to decrease the number of infections and the rising hospitalizations and death counts. Even as these events unfolded, new evaluations were taking place to understand the unique genetic composition of SARS$\mathrm{CoV}-2$ and its unexplained virulence. ${ }^{7}$ Moreover, given the nature of the Coro- 
navirus, a virus whose genetic information is packaged in the molecular form known as RiboNucleic Acid, or RNA, it was astonishing that a vaccine candidate that was based on a relatively new form of vaccinology that first showed efficacy in $1990,{ }^{8}$ entered Phase 1 clinical trials in mid-March 2020. ${ }^{9}$ In the long history of our knowledge of viruses, beginning with the tobacco mosaic virus in 1892, ${ }^{10}$ there has never been such a rapid response to an infectious invader.

In Shakespeare's The Tempest, characters Antonio and Sebastian are contemplating their fate - to commit murder - an act that was rationalized by all that had come before, speaks Antonio,

"And by that destiny to perform an act whereof what's past is prologue, what to come in yours and my discharge."

That their history determined their fate, and not their decisions and choices to come, suggests that the past events form the prologue for Shakespeare's story. The title of this paper suggests that, as in The Tempest, our past experiences with global pandemics in the $20^{\text {th }}$ century [1918 Influenza (H1N1), 1957 "Asian flu" (H2N2), 1983 Acquired Immune Deficiency Syndrome (HIV)] are perhaps a prologue of the next act in infectious diseases. Just as Antonio and Sebastian had choices, so we do as well.

Here, I turn back the clock on discoveries to reveal the dilemma of 1918. Although discovered by Antonie von Leeuwenhoek in 1676, the nature of bacteria and their connection to fermentation (Louis Pasteur) and disease (Robert Koch) would not be made until the late $19^{\text {th }}$ century, during what was known as "The Great Sanitary Awakening." ${ }^{11}$ At this time, the average life expectancy in the U.S. was fewer than 40 years (Figure 1 , page 4$)^{12}$ Joseph Lister (yes, he in- vented Listerine) recognized the importance of sanitized hands and equipment in medical procedures. In Berlin, Koch studied numerous $19^{\text {th }}$-century pandemic diseases, including cholera and anthrax, and became the father of medical bacteriology, the germ theory of diseases, Koch's postulates, and public health. He developed a potential treatment for tuberculosis, for which he was awarded only the third Nobel Prize in medicine, and life expectancies began to turn higher. Bacteria and bacteriology would play an important role in the prologue to the 1918 influenza pandemic. ${ }^{5}$

As Fig. 1 illustrates, the average life expectancy for the latter half of the $19^{\text {th }}$ century was essentially flat, with the exception of the mid-1860s and the impact of the Civil War, around 40 years (point 1). The lessons from "The Great Sanitary Awakening" led to a steady climb in longevity, primarily from improved infant mortality rates, which were as high as $20 \%$ into the early $20^{\text {th }}$ century in the U.S. Improved working conditions in factories, the introduction of the electrostatic precipitator in coal fired furnaces and power plants, ${ }^{13}$ and a migration of the population from rural to urban living helped to improve public health overall; however, this latter point would prove to be a significant challenge for disease control in the crowded cities in the U.S. and elsewhere. Notable deviations from the steady increase in longevity included the 1918 H1N1 influenza pandemic (point 2) and the effective end to childhood infectious diseases such as measles and polio (point 3) offset by the factors of smoking and the impact of cancers, heart disease, and unbalanced diets and lifestyle; although, all of these have been the focus of NIH funding in recent decades.

Bacteriology may have been the prologue to the 1918 pandemic, but it also 


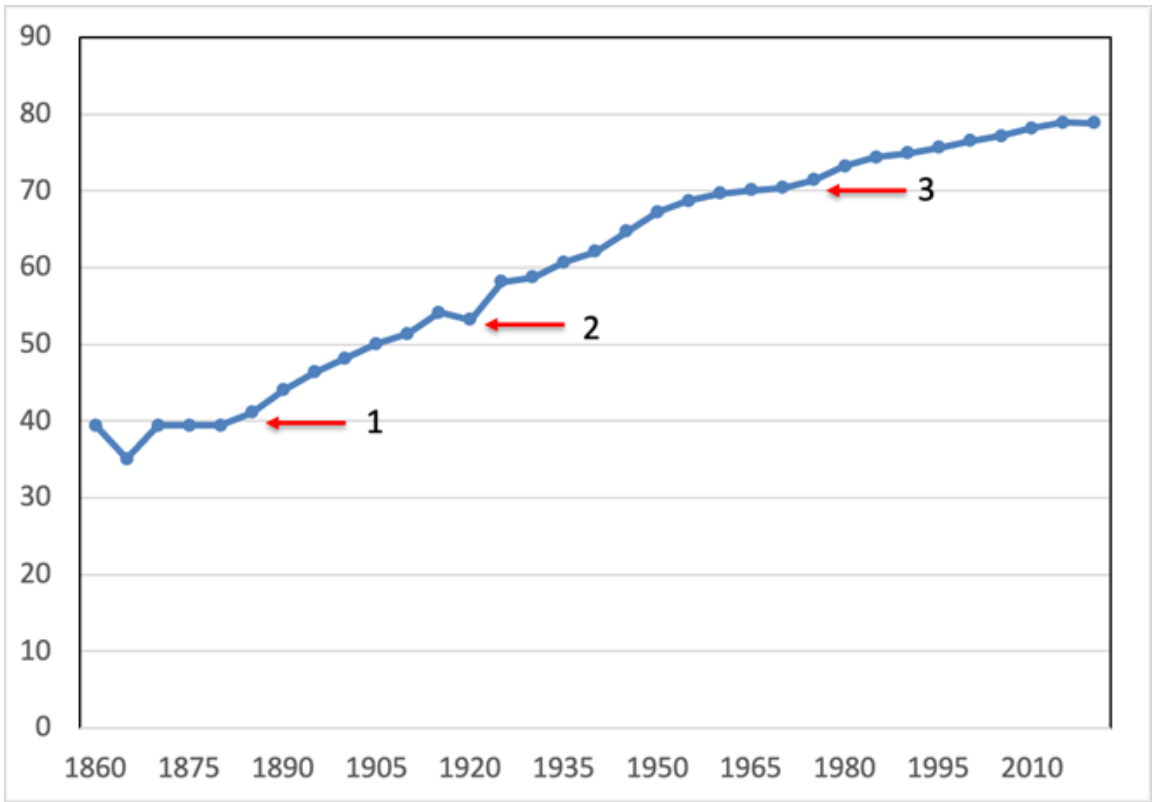

Figure 1. Life expectancy in years in the U. S. 1860-2020

created a tempest within the medical community as scientists attempted to understand the nature of the outbreak and how to best treat it. Bacteria under study in living organisms were determined to be "filterable" by removing bacteria from a solution of fluids taken from a diseased patient through culture treatment and filtration through a porcelain filter, in some cases yielding a "poisonous fluid" that contained a "disease" agent. ${ }^{14}$ The term "virus" comes from the Latin term for poison since the virus passed through into the poisonous filtrate. Viruses may also act as parasites in bacteria or protozoa and may not pass the "filtration" test; nevertheless, the work in Pasteur's lab (and later the Institute) would be influential in establishing some of the most significant treatments for diseases, such as rabies and diphtheria. As an aside, it is the study of viral infections of bacteria, and the ability of bacteria to "inoculate" its offspring to that virus, that led to the 2020 Nobel Prize in chemistry for the discovery of the CRISPR Cas9 process for gene editing by Charpentier and Doudna. ${ }^{15}$
At the time of the 1918 influenza outbreak, a new generation of bacteriologists and virologists was emerging from European and U.S. research universities; although the group would remain relatively small for another few decades. The past, for these researchers, was the rudimentary understanding of bacteria (microscopic) and viruses (in the filtrate and sub-microscopic, at that time). The studies of the earliest Nobel Laureates in medicine, together with the relatively new institutes in the U.S. (and the creation of the Marine Health Service, the prologue to the National Institutes of Health), were important foundations for relatively new scientists such as Oswald Avery and later Gertrude Elion, who would struggle with influenza and its viral mysteries but would discover new realms of science through their scientific choices.

Avery, who spent the 1918 pandemic collecting, isolating, and growing a bacterium called Bacillus influenza, noted that not all influenza patients had this mystery bacterium in their systems and that the filtrate from tissue "swabbing" could 
infect rabbits and other patients. Nevertheless, he pursued the $B$. influenza bacterium theory until the virus was isolated in 1930. Avery remained convinced that the symptoms of influenza, such as pneumonia, were caused by a bacterium, and he continued to study pneumococcus at the Rockefeller Institute in New York where he isolated two strains, $\mathrm{R}$ and $\mathrm{S}$, the latter of which had a protein "capsule" that acted like a shell, and it was the virulent bacillus. By transferring some cellular material from $S$ to the $\mathrm{R}$ strain, he could cause the $\mathrm{R}$ to grow a shell. He deduced that this cellular material must contain information that could cause one strain to grow into another: he had discovered the function of DNA. ${ }^{16}$ Moreover, his work on a pneumonia vaccine formed the basis for the current pneumonia vaccine, and his discoveries related to the function of DNA led to the pursuit of the structure by Francis Watson and James Crick, which led to their Nobel Prize in 1962.

The chemical building blocks for DNA are nucleic acids. Two nucleic acids are built from the chemical building block purine, adenine and guanine (or $A$ and $G$ for shorthand notation), which bind to two other nucleic acids, cytosine and thymine (C and T). A-T and C-G form "base pairs" that bind two strands of nucleic acids together to form the structure of DNA. The chemical class of purine compounds is extensive, and Gertrude Elion, a chemist at Burroughs-Wellcome in New York who was born on the eve of the 1918 influenza pandemic, would elucidate an important family of chemical compounds from purines that impacted how DNA could be interpreted by cellular components and ultimately how DNA could be rendered impotent. Her creative work led to antiviral and anticancer agents based on purines, including azidothymidine, $\mathrm{AZT},{ }^{17}$ that earned her the Nobel Prize in 1988. One of the current COVID-19 treatments involves the broad-spectrum antiviral medication Remdesivir, which is built from Elion's purine chemical framework.

These contributions represent examples of how research from the past serves as prologue to the "current present": from the early discoveries of bacteria and viruses and the state of medical understanding in the $19^{\text {th }}$ century to the challenges of responding to and managing a pandemic in 1918 and beyond. Avery and Elion are just two examples from this past century of chemical/biological research since the 1918 pandemic that illustrate how lessons learned from the past emerged into some of the most influential medical discoveries of the present, including treatments for the current SARS-CoV-2 virus.

There have been a few lessons learned this past century through many tempests of research. Emerging from the influenza pandemic of 1918, the Marine Health Services would become the National Institute(s) of Health in 1930. Since that time, the Federal investment in research with the NIH has totaled roughly $\$ 1$ trillion; the total financial loss and cost of recovery from the COVID-19 pandemic was estimated at \$16 trillion. ${ }^{18}$ Investments in fundamental science, which led in the past to new chemical and biological techniques that enabled us to unravel the genomes of humans and other organisms, will continue to shine a light on the diversity of pathogens we may confront and how to do battle with them. Fundamental research led to the discovery of messenger RNA (mRNA) and its role in developing vaccines against RNA viruses, which enabled us to spool up vaccine candidates within a matter of weeks following the sequencing of the SARS-CoV-2 genetic code. If the past is prologue for the next 
century of discoveries, then surely we are on the brink of some wonderful things.

For those wonderful things to be realized, there are still challenges ahead for the global research enterprise. Funding is only part of the formula. In the U.S., there remain significant differences among communities of people who have access to medical treatments, let alone to education and participation in the discovery process. The 2019-2021 pandemic has revealed significant inequities in access, and it is incumbent upon the leadership in higher education to respond to those inequities of access to education and discovery by creating environments of inclusion and belonging for those from backgrounds that are different from the majority. The stories of post-1918 pandemic discoveries are peppered with inequities between men and women, "national" and "international," and white and non-white scientists. ${ }^{5}$ The past should not write the prologue for our diversity and inclusion efforts; in particular, this quote from John Dewey in The New Republic from 1934 is telling:

"Those who contend that intelligence is capable of exercising a significant role in social affairs and that it would be well if it had a much larger influence in directing social affairs can readily be made to appear ridiculous. From the standpoint of past human history it not only appears but is ridiculous. It takes little acquaintance with the past to realize what the forces have been that have determined social institutions, arrangements and changes. There has been oligarchical despotic power, political, ecclesiastic and economic, sometimes exercised openly, more often by all sorts of indirect and subtle means. Habit, custom and tradition have had a weight in comparison with which that of intelli- gence is feeble. Custom and tradition have originated in all sorts of ways, many of them accidental. But, once established, they have had weight independent of the conditions of their origin and have reinforced the power of vested interests. At critical times, widespread illusions, generated by intense emotions, have played a role in comparison with which the influence of intelligence is negligible." 19

More modern perspectives suggest that change is possible; however, Dewey isn't far off in recognizing that culture can eat strategy for lunch. Fiona Murray wrote in Science that by studying inventors and inventions of products for women, female inventors made significantly improved products for women. ${ }^{20}$ The future of invention and innovation, which improves ideas and products for all, must include diversity of thought. We must continually examine our teams and inputs and ask, "Who or what is missing?" from our innovation. Different perspectives, views, and experiences need to be part of our scientific lexicon, because changing the culture takes many steps and a lot of time.

I will conclude with another viewpoint from The Tempest; a passage that may be more uplifting than that of Antonio and Sebastian contemplating murder or John Dewey arguing that intelligent strategies for change are ridiculous. A passage that suggests that the prologue of tomorrow may be written by our willingness to improve today:

"O wonder!

How many goodly creatures there are here!

How beauteous mankind is!

O brave new world,

That has such people in't!"

- Miranda, The Tempest (Act V.S1.) 


\section{References}

1. Coalition for Epi Response, Engagement, and Science: https://www.research. colostate.edu/ceres-agricultural-biosecurity/

2. a) Lau, S. K., Woo, P. C., Li, K. S., et al. (2005). Severe acute respiratory syndrome coronavirus-like virus in Chinese horseshoe bats. Proceedings of the National Academy of Sciences of the United States of America, 102 (39): 14040-14045. b) National Academies of Sciences, Engineering, and Medicine, Division on Earth and Life Studies, Board on Life Sciences, Board on Chemical Sciences and Technology, Committee on Strategies for Identifying and Addressing Potential Biodefense Vulnerabilities Posed by Synthetic Biology. (5 December 2018). Biodefense in the Age of Synthetic Biology. Washington, DC: National Academies Press, pp. 44-45.

3. Rudolph, A., Nusser S., Stover, P., Mohapatra, P., Wilhelm, R., \& Dorhout, P. (2019). Lincoln's Biodefense Strategy: Protecting the Agricultural Base. Health Security, 17.

4. World Health Organization web site for tracking COVID-19: https://covid19.who. int/region/amro/country/us

5. Barry, J. M. (2004). The Great Influenza. New York: Viking Penguin.

6. A portion of these remarks were also published in: (2020) Seek Magazine, Manhattan, KS: New Prairie Press. P. 3.

7. Jiang, T., et al. (2020). Genome Composition and Divergence of the Novel Coronavirus (2019-nCoV) Originating in China. Cell Host Microbe, 27(3), pp. 325-328.

8. Pardi, N., Hogan, M. J., Porter, F. W., \& Weissman, D. (2018). mRNA Vaccines - a New Era in Vaccinology. Nature Reviews Drug Discovery, 17, pp. 261-279.

9. NIH News Release. (March 16, 2020. NIH clinical trial of investigational vaccine for COVID-19 begins. https://www.nih.gov/news-events/news-releases/nih-clinical-trial-investigational-vaccine-covid-19-begins. This was the Moderna mRNA vaccine in its Phase 1 clinical trial in Seattle, WA.

10. Woolhouse, M., Scott, F., Hudson, Z., Howey, R., \& Chase-Topping, M. (2012). Human Viruses: Discovery and Emergence. Philos Trans R. Soc. Lond. B Biol. Sci., 367 (1604), pp. 2864-71.

11. Institute of Medicine (US) Committee for the Study of the Future of Public Health. (1988). A History of Public Health. Washington (DC): National Academies Press (US).

12. O'Neill, A. (2021). Life Expectancy in the U. S. 1860-2020. https://www.statista.com/ statistics/1040079/life-expectancy-united-states-all-time/

13. Research Corporation for Science Advancement archives (accessed in July 2021) and history of Frederick Gardner Cottrell. https://rescorp.org/gdresources/docs/ RC-ARCHIVES-box-folder-list-march-2013.pdf

14. Taylor M. W. (2014). Introduction: A Short History of Virology. Viruses and Man: A History of Interactions, 1-22.

15. Uyhazi, K. E., \& Bennett, J. (2021). A CRISPR view of the 2020 Nobel Prize in Chemistry. J. Clin. Invest., 131(1), 1-3.

16. Avery, O. T., MacLeod, C. M., \& McCarty, M. (1944). Studies on the Chemical Nature of the Substance Inducing Transformation of Pneumococcal Types. J. Exp. Med., 79(2) pp. 137-158.

17. Reeves, J. D., \& Derdeyn, C. A. (2007). Entry Inhibitors in HIV Therapy. Springer Science $\mathcal{E}$ Business Media, p. 179. 
18. Cutler, D. M., \& Summers, L. H. (2020). The COVID-19 Pandemic and the $\$ 16$ Trillion Virus. JAMA, 324(15):1495-1496.

19. Dewey, J. (1934). Intelligence and Power. The New Republic.

20. Murray, F. (2021). Mothers of Invention. Science, 372: pp. 1260-1262. 